Kontribusi Tafsir... Oleh: Muslimin

\title{
KONTRIBUSI TAFSIR MAUDHU'I DALAM MEMAHAMI AL-QURAN
}

\author{
Oleh: \\ Muslimin \\ musliminmpdi3@gmail.com \\ Institut Agama Islam Tribakti (IAIT) Kediri
}

\section{Abstrak}

Secara singkat tafsir maudhu'i atau tafsir tematik dapat diformulasikan sebagai suatu tafsir yang berusaha mencari jalan keluar dari masalah-masalah yang timbul seputar alQuran tentang kejadian-kejadian baru dengan jalan menghimpunkan ayat-ayat yang berkaitan dengannya. Kemudian dianalisis melalui ilmu-ilmu bantu yang relevan dengan masalah-masalah yang dibahas, sehingga dapat melahirkan konsep-konsep baru yang akurat dari al-Quran tentang masalah yang dibahas. Metode yang relatif baru dan dianggap aktual dalam penafsiran al-Quran berangkat dari satu kesatuan yang logis dan saling berkaitan antara satu sama lainnya. Jadi tidak ada satupun kontradiksi ayatayat al-Quran, hal ini semakin jelas sebagaimana yang ditegaskan pula di dalam al-Quran itu sendiri. Asumsi dasar ini berkaitan dengan prinsip yang sangat masyhur di kalangan mufassir, yaitu bahwa sebagian ayat al-Quran dapat ditafsirkan dengan ayat yang lain. Sedangkan analisis tentang kelebihan dan kekurangan tafsir maudhu'i adalah sebagai berikut: kelebihan tafsir maudhu' $i$ adalah dapat menjawab tantangan zaman, lebih praktis, sistematis, dinamis dan mudah dipahami secara utuh. Sedangkan kelemahan dari tafsir maudhu'i biasanya adalah memenggal ayat al-Quran dari rangkaiannya dan membatasi pemahamannya disesuaikan dengan pokok bahasannya.

Kata Kunci: Kontribusi, Tafsir Maudhu'i, Memahami alQuran. 


\section{Pendahuluan}

Al-Qur'an adalah pedoman untuk umat manusia, petunjuk dan syari'at Allah untuk ahli bumi. Al-Qur'an adalah Kalamullah, petunjuk langsung dari Allah dan syari'at agama yang lengkap. Ia berisi ajaran-ajaran yang dibutuhkan oleh semua manusia baik urusan agama, dunia dan urusan akhiratnya. ${ }^{1}$ Al-Qur'an sebagai sebuah petunjuk tentunya harus dibaca, dipahami dan diamalkan. Dalam rangka untuk dapat memahami al-Qur'an tentunya diperlukan suatu cara atau kajian tafsir yang sesuai, sehingga kita dapat memahami makna-makna dari ayat-ayat al-Qur'an yang jelas dan gamblang dilalahnya sesuai yang dikehendaki oleh Allah.

Al-Qur'an diturunkan untuk menjelaskan ketentuanketentuan dan syari'at yang universal sesuai dengan konteks peristiwa dan kejadian dua puluh tahun lebih. Tetapi ajaran atau syari'at tersebut ada sebagian yang belum dapat dilaksanakan sebelum arti, maksud dan inti persoalannya betul-betul dimengerti dan dipahami oleh umat manusia.

Oleh karenanya, maka para sahabat Nabi dan tabi'in beserta para ulama salaf terus mempelajari al-Qur'an. Mereka menerangkan semua maksud ayat yang bersifat global, kemudian menjelaskan artinya yang samar-samar dan menafsirkan ayat tersebut yang dirasa sangat sulit dipahami, sehingga tidak ada lagi keraguan dan kesulitan bagi para sahabat, tabi'in dan para ulama' salaf. ${ }^{2}$

Dalam perkembangannya, kita mengenal beberapa metode tafsir antara lain tafsir tahlily, tafsir ijmaly, tafsir muqarran dan

1 Syaikh Muhammad' Ali Ash-Shobuny, Ath-Thibyan fi 'Ulum AlQur'an, terj. Muhammad Qodiron Nur, Ihtisar Ulumul Qur'an Praktis (Jakarta: Pustaka Amani, 1988), h.87

2 Abd. Al-Hayyi al-Farmawi, Al-Bidayah fi al-Tafsir al-Maudhu'iy, terj. Suryan A. Jamrah, Metode Tafsir al-Mawdhu'iy (Jakarta PT. RajaGrafindo Persada, 1994), h.2 
tafsir maudhu' $i$. Tentang metode tafsir maudhu' $i$ akan kita bahas lebih lanjut.

\section{Pembahasan}

\section{Definisi Tafsir Maudhu'i}

Secara etimologis, tafsir berarti keterangan dan penjelasan yang berlanjut mengenai isi kitab suci. ${ }^{3}$ Sebagaimana firman Allah :

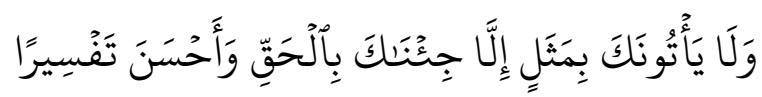

Terjemahnya : Tidaklah orang-orang kafir itu datang kepadamu (membawa) sesuatu yang ganjil, melainkan Kami datangkan kepadamu suatu yang benar dan yang paling baik penjelasannya .

Kata fassara (بين) berarti bayyana dan wadhaha (وضح). Adapun tafsir menurut arti istilah berarti ilmu untuk memahami kitab Allah yang diturunkan kepada Nabi Muhammad SAW menjelaskan maknanya, serta mengeluarkan hukum-hukum dan hikmahnya. ${ }^{5}$

Sedangkan tafsir maudhu'i secara istilah adalah menghimpun ayat-ayat al-Quran yang mempunyai maksud yang sama dalam arti sama-sama membicarakan satu topik masalah dan menyusunnya berdasar kronologi serta sebab turunnya ayatayat tersebut. Kemudian penafsir mulai memberikan keterangan dan penjelasan serta mengambil kesimpulan. Secara khusus penafsir melakukan studi tafsirnya dengan metode maudhu' $i$ di mana ia meneliti ayat-ayat tersebut dari seluruh seginya dan

3 J. S. Badudu, Kamus Bahasa Indonesia (Jakarta: Pustaka Sinar Harapan, 1994), h. 1396.

${ }^{4}$ Departemen Agama Republik Indonesia, Al-Qur'an Al-Karim dan terjemahan (Semarang: Thaha Putra, 1996), h. 289.

${ }^{5}$ Imam Badarrudin Muhammad bin Abdullah Al-Zarkasyi, Al-Burhan fi 'Ulum Al-Qur'an (Beirut: Dar Kitab Al-'Alamiyah, t.t.), h. 13. 
melakukan analisis berdasarkan ilmu yang benar yang digunakan oleh pembahas untuk menjelaskan pokok permasalahan, sehingga ia dapat memahami permasalahan tersebut dengaan mudah dan betul-betul menguasainya, sehingga memungkinkan baginya untuk memahami maksud yang terdalam dan dapat menolak segala kritik. ${ }^{6}$

\section{Sejarah Tafsir Maudhu'i}

Pertumbuhan atau perkembangan, metode tafsir ini telah ada semenjak zaman Nabi Muhammad. Hal ini terbukti dari adanya sebuah riwayat tentang penafsiran kata ظلم oleh Nabi pada ayat : الذين امنوا ولم يلبسوا ايمنهم بظلم dengan makna pada ayat أن الثرك لظلم عظيم Di mana Nabi Muhammad SAW. menyampaikan ilmu pengetahuan kepada para sahabat untuk mengumpulkan beberapa ayat mutasyabihat akan mempermudah untuk mengetahui pokok bahasan dan akan menghilangkan keraguan. Penafsiran ayat dengan ayat tersebut menjadi pendahuluan bagi munculnya metode tafsir maudhu' $i{ }^{7}$

Pada perkembangan selanjutnya, banyak kita temui benih tafsir maudhu' $i$ yang bertebaran di dalam kiatb tafsir, hanya saja masih dalam bentuk yang sederhana sehingga belum dapat dikatakan sebagai metode yang berdiri sendiri karena masih dalam bentuk yang sangat ringkas.

Dari hal di atas, kita dapat ketahui bahwa metode tafsir maudhu'i sudah ada sejak dahulu dengan bentuknya yang mulamula, belum dimaksudkan sebagai metode yang memiliki karakter metodologis yang berdiri sendiri. Walaupun demikian paling tidak menunjukkan kepada kita bahwa metode tafsir ini bukanlah hal baru dalam sejarah studi al-Qur'an, yang baru bukan metodenya tetapi perhatian para ulama terhadap

${ }^{6}$ Lihat Ali Khali, al-Muzakkarat al Khathiyyah, Muhammad Hijazi, al-Wahdah al Mawdhu'iyyah, h. 25.

${ }^{7}$ Abdul Hayyi Al-Farmawi, h. 38. 
penggunaan metode tersebut, suatu metode yang dapat memberikan informasi tentang berbagi ilmu, berbeda dengan metode tafsir lainnya dan betul-betul sebagai metode tersendiri otonom. ${ }^{8}$

\section{Varian dan Cara Kerja Tafsir Maudhu'i}

Di dalam menggali hukum-hukum yang terdapat dalam ayat al-Qur'an, kajian tafsir maudhu'i mempunyai dua bentuk: Pertama, pembahasan mengenai satu surat secara menyeluruh dan utuh dengan menjelaskan maksudnya yang bersifat umum dan khusus, menjelaskan korelasi antara beberapa masalah yang dikandungnya, sehingga surat ini tampak utuh dan sempurna, sebagai contoh adalah surat Saba. Kedua, mengumpulkan beberapa ayat dari banyak surat yang serupa yang sama-sama membicarakan masalah tertentu. Kemudian ayat-ayat itu dirangkai sedemikan rupa pada satu tema pokok bahasan dan selanjutnya ditafsirkan secara maudhu'i. Cara yang demikian ini disebut tafsir maudhu'i. ? $^{\text {? }}$

Dalam menggunakan metode tafsir maudhu'i terdapat cara-cara tersendiri atau tahapan-tahapan yang dapat dilakukan anatara lain:

1. Mencari dan menetapkan masalah-masalah yang ada dalam al-Qur'an yang menjadi pokok bahasan

2. Mencari dan mengumpulkan ayat-ayat makiyah dan madaniyah.

3. Mengumpulkan ayat-ayat secara teratur menurut kronologi masa turunnya, serta latar belakang turunnya ayat atau asbab al-nuzul.

4. Menganalisis beberapa ayat secara tematik dengan mengumpulkan ayat-ayat al-Qur'an yang mempunyai pengertian hampir sama, mengompromikan ayat yang 'am

${ }^{8}$ Abdul Hayyi Al-Farmawi, h. 38-40.

${ }^{9}$ Abdul Hayyi Al-Farmawi, h. 35-36.

Volume 30 Nomor 1 Januari-Juni 2019 
Kontribusi Tafsir... Oleh: Muslimin

dan khas antara yang muthlak dan yang muqoyyad mensinkronkan ayat-ayat yang lahirnya tampak kontradiktif, menjelaskan ayat nasikh dan mansukh sehingga semua ayat tersebut bertemu pada suatu muara tanpa perbedaan dan kontradiksi atau tindakan pemaksaan terhadap sebagian ayat kepada makna-makna yang sebenarnya tidak tepat. ${ }^{10}$

\section{Perbedaan antara Metode Tafsir Maudhu'i dan Metode Lain}

Sebelum lebih jauh membahas perbedaan antara metode tafsir maudhu' $i$ dengan beberapa metode tafsir yang lainnya, ada baiknya dikemukakan terlebih dahulu pengertian dari beberapa metode tafsir tersebut. Pertama, metode tafsir al-tahlily, adalah suatu metode tafsir yang bermaksud menjelaskan kandungan ayat-ayat al-Quran dari seluruh aspek-aspeknya, dalam tafsirnya penafsir mengikuti runtutan ayat sebagaimana yang tersusun di dalam mushaf. ${ }^{11}$

Kedua, metode tafsir muqorrin, yaitu metode tafsir yang menampilkan penafsiran ayat-ayat al-Quran yang ditulis oleh sejumlah penafsir di mana seorang mufassir menghimpun sejumlah ayat-ayat al-Quran kemudian mengkaji dan meneliti penafsiran sejumlah penafsir mengenai ayat tersebut melalui kitab-kitab tafsir mereka, apakah mereka penafsir dari generasi salaf ataupun khalaf. ${ }^{12}$ Berikut penjelasan mengenahi perbedaan metode tafsir mawdhu'i dengan metode tafsir tahlily

1. Perbedaan tafsir mawdhu'i dan tafsir tahlily

a. Dalam metode tafsir tahlily penafsir sering tepaku pada teks ayat al-Quran dengan apa adanya. Adapun metode tafsir mawdhu'i tidak seperti itu.

\footnotetext{
${ }^{10}$ Abdul Hayyi Al-Farmawi, h. 45-46.

${ }^{11}$ Abdul Hayyi Al-Farmawi, h. 12.

12 Abdul Hayyi Al-Farmawi, h. 30.
} 
b. Dalam metode tahlily, mufasir dapat mengemukakan uraian tentang macam-macam masalah yang ditemukan pada setiap ayat dan surat sedang dalam metode maudhu'i seorang mufasir mengonsentrasikan pembahasannya hanya pada pokok bahsan. Dengan cara ini satu masalah akan dibahas secara tuntas tanpa melibatkan masalah yang lain.

c. Dalam metode maudhu'i permasalahan dalam al-Quran mudah ditelusuri, dengan pembahasan yang mungkin dapat mengungkap petunjuk al-Quran secara baik, sedangkan melalui metode tahlily seseorang mungkin merasa sulit untuk memahami hal yang sedemikian. ${ }^{13}$

2. Perbedaan tafsir maudhu' $i$ dengan tafsir muqorrin

a. Metode tafsir mawdhu'i berkonsentrasi pada satu pokok bahasan sedang metode muqorrin berusaha menggabungkan satu ayat al-Quran dengan yang lainnya yang sudah dibahas oleh mufassir terdahulu.

b. Dalam tafsir maudhu'i agar dapat mencapai tujuan yang ditentukan harus mengumpulkan banyak ayat atau sedikit ayat yang ada hubungannya dengan pokok bahasan yang dikaji serta berusaha membahas topik tersebut berdasarkan kemampuan para mufassir dari ayat-ayat tersebut. Sedangkan metode muqorrin agar dapat sampai pada tujuan harus meneliti terlebih dahulu sejumlah ayat-ayat tertentu kemudian menganalisis hasil temuan para penafsir dan juga harus membandingkan dari berbagai arah.$^{14}$

${ }^{13}$ Abdul Hayyi Al-Farmawi, h. 49.

${ }^{14}$ Abdul Hayyi Al-Farmawi, h. 7. 
Kontribusi Tafsir... Oleh: Muslimin

\section{Urgensi dan Keutamaan Tafsir Maudhu'i}

Untuk mengenal betapa pentingnya keberadaan corak dan metode tafsir maudhu'I ada beebrapa faedah dan keistimewaan metode maudhu'i yang dimaksud, yaitu :

1. Dengan menghimpun beberapa ayat para mufassir akan menemukan adanya keserasian dan korelasi antara ayat satu dengan ayat yang lain.

2. Dengan mengumpulkan beberapa ayat atau sebagian ayat penafsir akan dapat menemukan hasil yang relatif sempurna terhadap pokok masalah yang dibahas.

3. Corak kajian tafsir maudhu'i ini sesuai dengan semangat zaman modern yang menuntut kita berupaya melahirkan suatu hukum yang bersifat universal untuk masyarakat Islam yang bersumber al-Quran yang mudah dipahami dan diterapkan. ${ }^{15}$

Adapun keutamaan metode tafsir maudhu'i adalah kesimpulan yang dihasilkan oleh metode tafsir maudhu'i mudah dipahami. ${ }^{16}$ Sedangkan kelemahan metode tafsir maudhu'i adalah seorang penafsir harus memfokuskan diri pada satu pokok bahasan. ${ }^{17}$

\section{Penutup}

Dari pembahasan di atas, kita telah dapat mengenal sedikit tentang penafsiran al-Qur'an dengan metode maudhu'i, yang mana metode ini ada klaim muncul baru-baru ini saja. Akan tetapi metode tersebut kalau dilihat dari kaca sejarah sudah ada semenjak zaman Nabi masih hidup.

Pada perkembangan selanjutnya metode ini diperlukan untuk muncul kembali pada era sekarang adalah karena

15 Abdul Hayyi Al-Farmawi, h. 51-54

${ }^{16}$ Quraisy Shihab, Membumikan Al-Qur'an (Jakarta : Mizan, 1994), h. 117

${ }^{17}$ Shihab, Membumikan Al-Qur'an, h. 120. 
hilangnya orang-orang yang hafal al-Quran dan memiliki kedalaman ilmu keislaman di kalangan putra-putri Islam dan sulitnya bagi orang-orang asing (non-Arab), muslim maupun non-Islam untuk memahami al-Quran langsung melalui bahasanya.

Dan pada perkembangan berikutnya ternyata sampai sekarang kajian melalui metode tafsir maudhu'i ini dirasa cocok dan banyak digunakan oleh para mufassir di zaman modern ini yang mana mereka dituntut untuk mengetengahkan hukumhukum yang universal yang mudah dipahami oleh masyarakat Islam. 


\section{DAFTAR PUSTAKA}

Badudu, J. S. Kamus Bahasa Indonesia. Jakarta: Pustaka Sinar Harapan, 1994.

Departemen Agama Republik Indonesia. Al-Qur'an Al-Karim dan terjemahan. Semarang: Thaha Putra, 1996.

Farmawi, Abd. Al-Hayyi al-. Al-Bidayah fi al-Tafsir alMaudhu'iy, terj. Suryan A. Jamrah, Metode Tafsir alMawdhu'iy. Jakarta PT. RajaGrafindo Persada, 1994.

Shihab, Quraisy. Membumikan Al-Qur'an. Jakarta: Mizan, 1994.

Shobuny, Syaikh Muhammad' Ali Ash-. Ath-Thibyan fi 'Ulum Al-Qur'an, terj. Muhammad Qodiron Nur, Ihtisar Ulumul Qur'an Praktis. Jakarta: Pustaka Amani, 1988.

Zarkasyi, Imam Badarrudin Muhammad bin Abdullah Al-. AlBurhan fi 'Ulum Al-Qur'an. Beirut: Dar Kitab Al'Alamiyah, t.t. 